\title{
Energy performance and building regulations
}

Received (in revised form): 20th August, 2007

\section{Katherine Campbell}

is a senior associate solicitor in the Birmingham office of Reed Smith Richards Butler LLP, specialising in complex real estate litigation. She is a public speaker, speaking to audiences of surveyors and lawyers around the country and has published articles in specialist, regional and national press. She has particular expertise in matters involving insolvency and upon the regulatory framework as it affects property professionals, landlords and tenants.

Correspondence: Katherine Campbell, Reed Smith Richards Butler LLP, Trigen House, Central Boulevard, Blythe Valley Park, Solihull B90 8AB, UK; Tel: +44 (0) 121210 6158; Fax: +44 (0) 121210 6499; E-mail: kcampbell@reedsmith.com

\begin{abstract}
Energy performance of buildings is high on the Government's agenda. Fifty per cent of all carbon dioxide emissions come from buildings and with a goal of reducing carbon dioxide emissions by 60 per cent on 1990 levels by 2050, the Government has its work cut out. Amongst the raft of legislation, both national and international, the European Performance of Buildings Directive has particular significance. The UK is presently working its way towards complete compliance with the directive as it applies to the energy performance of new and existing buildings. Energy certification is a reality and with the EUs Action Plan on Energy Efficiency set to expand upon the requirements already in place, this is one bundle of red tape that cannot be ignored.

Journal of Building Appraisal (2007) 3, 231-235. doi:10.1057/palgrave.jba.2950077
\end{abstract}

\section{Keywords:}

energy performance, energy efficiency, energy certificates, green buildings

\section{INTRODUCTION}

The UK Government has a goal of cutting the UK's carbon dioxide emissions by 60 per cent on 1990 levels by 2050 with real progress in the region of reductions of 50-75 million tons of carbon being made by 2020. To date, we have achieved a reduction in greenhouse gas emissions of 16 per cent below 1990 levels and it is anticipated that that figure will increase to 24 per cent by 2010.

Following Europe's lead by the introduction of the European Energy Performance of Buildings Directive (EPBD), there has been a raft of legislative activity in the UK. The Government's Energy White Paper was published in 2003, followed by its Action Plan for Energy Efficiency in 2004. In addition, an Energy Review was announced in November 2005 to review the progress made towards meeting the goals set out in the Energy White Paper. The 2006 Climate Change and sustainable Energy Act received royal assent on 21st June, 2006 and an EU Energy Efficiency Action Plan, to be implemented over the next six years, has recently been announced. This has a target of reducing energy consumption by 20 per cent across the EU by 2020 and will expand the EPBD (see below). Most recently, a white paper on energy has been published, called Meeting the Energy Challenge, which annexes the fourth annual report on progress towards the 2003 Energy White Paper goals.

As part of the Government's implementation of the EPBD, effective from 6th April, 2006, the Government has amended energy requirements contained within Part L of the 
Building Regulations, in particular requirements relating to efficiency of boilers and ventilation systems and energy saving insulation and a Planning White Paper on climate change has recently been published, in which the location and design of new developments and the use of renewable energy sources is addressed.

\section{COMPLIANCE}

In order to ensure compliance with all this primary and secondary legislation, the Climate Change and Sustainable Energy Act 2006 means that local authorities will be able to prosecute for breaches of energy efficiency standards within six months of discovering the breach, rather than within six months of completion of the relevant work, as was previously the case.

The local Government White Paper, issued in Autumn 2006 will devolve greater powers and responsibilities to local authorities in respect of climate change policies. In Wales, all local authorities have signed a declaration committing them to producing a climate change action plan. In London, the Mayor has published London's own energy strategy.

The much talked-about energy certification in respect of existing homes was deferred this summer, at least in part, through action taken by the RICS to challenge the legality of the Government's proposals. Notwithstanding, the Government maintains a long-term ambition of carbon neutral development. To achieve this, it proposes the following:

- to set energy efficiency levels for the Code for Sustainable Homes;

- for these levels to govern the future direction of Building Regulation;

- to renew the Building Regulations guidelines in order to improve compliance;

- to require government-funded housing to meet at least level 3 of the code;

- to introduce Energy Performance Certificates for new and existing houses;

- to develop a new Planning Policy Statement on climate change;

- to urge planning authorities to set ambitious policies on renewable energy.

\section{THE EPBD}

About 50 per cent of all carbon dioxide emissions come from buildings: about 30 per cent from dwellings and 20 per cent from other buildings. The EPBD therefore has wide implications for owners, operators and developers of all buildings in the UK, both domestic and commercial. Clearly this is a major driver for present Government activity in the UK. Initially the EPBD was to be implemented into UK Legislation by 4th January, 2006. This was put back to 6th April, 2006, but certain parts of the EPBD have yet to be implemented. The EU Energy Efficiency Action Plan aims to expand the provisions of the EPBD even further in 2009, including its remit over smaller buildings.

The EPBD's key provisions are:

- Establishing a calculation methodology for energy performance of buildings.

- Minimum requirements for the energy performance of all new buildings.

- Minimum requirements for the energy performance of existing large buildings subject to major renovation.

- Energy Certification of all buildings.

- Regular mandatory inspection of boilers and air conditioning systems in buildings. 


\section{CALCULATION METHODOLOGY}

The UK has devised a system for the calculation of energy performance in respect of nondomestic buildings. The tool, the Simplified Building Energy Model (SBEM), is a programme that provides an analysis of a building's energy consumption, calculating energy use and carbon dioxide emissions.

For domestic buildings, the existing Standard Assessment Procedure (SAP) will be used and has been extended to ensure compliance with the EPBD.

\section{MINIMUM REQUIREMENTS FOR ENERGY PERFORMANCE}

The Building and Approved Inspectors (Amendment) Regulations 2006 amended the Building Regulations in England and Wales with effect from 6th April, 2006. The current set of new approved documents are:

- L1A for new dwellings;

- L1B for existing dwellings;

- L2A for new nondomestic buildings and

- L2B for existing nondomestic buildings.

It will have to be demonstrated that the annual carbon dioxide emissions from a building will not exceed a target level established by reference to the calculated emissions from a notional gas heated building of the same size and shape as the proposed building. SBEM will be the calculation tool applied.

The EPBD also requires consideration be given to low and zero carbon energy supply systems before construction starts, but incorporation is not yet compulsory for compliance with Part L, provided that a lesser provision is compensated by other energy efficiency measures. The calculation of carbon dioxide emissions on a whole-building basis amounts to a major change in the way new buildings are assessed for the purposes of Part L.

Approved document L2A provides that for new nondomestic buildings to comply with the requirements, they must:

- meet the carbon dioxide emissions target;

- demonstrate key design parameters are within defined limits;

- demonstrate the building will not be subject to high temperatures in Summer as a result of solar gains;

- provide evidence of the quality of construction;

- demonstrate that fixed building services achieve the carbon dioxide emissions target;

- provide information to enable occupiers to operate the building efficiently.

Approved document L2B which applies to existing nondomestic buildings encompasses improved performance standards and provides more guidance on the construction of extensions and upon consequential improvements required when a building over $1,000 \mathrm{~m}^{2}$ is extended.

Article 6 of the EPBD requires that when existing buildings with a total usable floor area of over $1,000 \mathrm{~m}^{2}$ undergo major renovation, energy performance must be upgraded to meet the minimum energy performance requirements. Further, a feasibility study of alternative HVAC and other systems must be considered and taken into account before construction begins on any building with a total usable floor area of more than $1,000 \mathrm{~m}^{2}$. 


\section{CERTIFICATION}

Article 7 of the EPBD requires that whenever a building is constructed, sold or rented a certificate detailing its energy performance must be made available. In addition, if a building has a total usable floor area of over $1,000 \mathrm{~m}^{2}$, is occupied by a public authority or institution providing public services, it is also required that the Energy Certificate is placed in a prominent place on display.

Although we now have the method for calculating energy performance, certification in respect of nondomestic buildings is unlikely to be implemented fully until the end of 2008, with April 2008 as a target date for smaller buildings and October 2008 for buildings over $1,000 \mathrm{~m}^{2}$. The Certificate must incorporate any recommendations for cost-effective measures that could lead to the improvement of the building's energy performance.

Introduction of certification will have obvious effects on property values. Where a property's Certificate incorporates proposals for improvements, it is likely to be worth less than its neighbour where no improvements are required. Corporate Social Responsibility will dictate that highly rated energy efficient buildings will be able to attract stronger covenants and no organisation concerned about such issues will wish to occupy a low rated building. Presumably a higher rating would also make a difference upon rent review if it can be shown that the hypothetical tenant would make an increased bid.

There is concern among developers that certificates will shorten the life span of properties constructed before the Regulations came into force and that the capital value of inefficient buildings will fall. However, those buildings will be able to offset this by carbon sequestration, using such routes as reforestation. In this way, directors' reporting requirements will be greatly assisted where otherwise an older building would attract a very poor rating.

\section{INSPECTION AND THE INSPECTORS}

Certification of buildings and inspection of boilers and air conditioning systems must be carried out by an independent and accredited expert. It is estimated that around 7,500 fulltime assessors will be needed to comply with the EPBD's requirements. The relevant professional institutions will have to gear up to the training and accreditation of such experts and it seems clear that the same difficulties which faced the implementation of the Asbestos Regulations will be faced here. The EPBD provides that if a member state could demonstrate that the EU suffered from a dearth of qualified or accredited experts, that state could delay the introduction of the EPBD for up to three years (hence the January 2009 longstop target set by the UK).

With regard to inspection of boilers, the option favoured by the UK is for government advice to be given upon the replacement of boilers and modifications to heating systems, including assessment of the efficiency and size of a boiler. Air conditioning systems will have to be regularly inspected where they have an output of more than $12 \mathrm{KW}$ and again an assessment of the efficiency and size of the system must be carried out and appropriate advice given on possible improvements or alternatives.

The EU's Action Plan on Energy Efficiency proposes new minimum performance requirements for new and renovated buildings and the current trigger of $1,000 \mathrm{~m}^{2}$ for renovations will be lowered to include the majority of buildings. Passive heating and cooling technologies are to be a requirement by the end of 2008 and a strategy for very low energy or passive housing is to be developed by 2015 . 


\section{THE IMPACT OF SUSTAINABLE ENERGY AND CLIMATE CHANGE REGULATION}

It is possible, if not probable, that plant and equipment will need to be replaced even where it is not beyond economic repair, as a result of the new regulations. Service charge provisions in leases will not generally allow a landlord to recover the cost of works which amount to improvement. As with the Asbestos Regulations, it may be possible for the landlord to recover the cost of compliance through service charge provisions or the statutory compliance clauses.

In an FRI lease, the provisions will have an effect upon terminal dilapidation claims where plant and equipment must be replaced rather than repaired. There will be no obligation upon a tenant to fund the cost of replacement of any item that is not in disrepair and therefore serious concentration upon statutory compliance clauses and service charge clauses will be necessary.

The testing of equipment is bound to lead to conflicts over liability for failure in design and construction, leading to claims against Architects, Project Managers and Contractors. Standard warranties will need to be reviewed.

Reputation is all important. Investors have already announced they may boycott companies that fail to meet socially responsible standards in energy efficiency. Directors reporting duties are becoming increasingly focussed towards environmental issues. Companies providing services to the public sector are often already required as part of the tendering process to demonstrate carbon neutral status.

The Property Industry will not be able to ignore this particular bundle of red tape. In time, it will have an effect on the bottom line if it is not addressed seriously and quickly. 